PLANT STRUCTURE, FUNCTION AND ADAPTATION 


\title{
PLANT STRUCTURE, FUNCTION AND ADAPTATION
}

\author{
Edited by \\ M. A. HALL \\ Department of Botany and Microbiology \\ University College of Wales, Aberystwyth
}


๑) The Macmillan Press Ltd 1976

All rights reserved. No part of this publication may be reproduced or transmitted, in any form or by any means, without permission

First edition 1976

Reprinted 1978, 1982

Published by

THE MACMILLAN PRESS LTD

London and Basingstoke

Companies and representatives

throughout the world

ISBN 978-0-333-14763-4 (hard cover)

ISBN 978-0-333-34455-2

ISBN 978-1-349-06571-4 (eBook)

DOI 10.1007/978-1-349-06571-4

The paperback edition of this book is sold subject to the condition that it shall not, by way of trade or otherwise, be lent, resold, hired out, or otherwise circulated without the publisher's prior consent in any form of binding or cover other than that in which it is published and without a similar condition including this condition being imposed on the subsequent purchaser. 


\section{Contents}

Preface $\quad$ x

List of Contributors xii

1. The Structure of Nucleic Acids and Proteins and their Function in Subcellular Assembly

DNA Synthesis

Chromosome structure

Semi-conservative replication of DNA $\quad 6$

Enzymes of DNA synthesis $\quad 7$

$\begin{array}{ll}\text { RNA Synthesis } & 10\end{array}$

$\begin{array}{ll}\text { Ribosomal RNA } & 10\end{array}$

$\begin{array}{ll}\text { Transfer RNA } & 13\end{array}$

$\begin{array}{ll}\text { Messenger RNA } & 14\end{array}$

$\begin{array}{ll}\text { RNA polymerase } & 17\end{array}$

$\begin{array}{ll}\text { The maturation of RNA } & 19\end{array}$

$\begin{array}{lr}\text { Protein Synthesis } & 21\end{array}$

Aminoacyl-tRNA $\quad 22$

Interaction of tRNA with mRNA: the genetic code 24

$\begin{array}{ll}\text { Polysomes } & 25\end{array}$

The control of initiation, elongation and termination 27

$\begin{array}{ll}\text { Folding the polypeptide chain } & 30\end{array}$

Subcellular Assembly $\quad 32$

$\begin{array}{ll}\text { Mitosis and the cell cycle } & 32\end{array}$

The role of nucleic acids and proteins in the assembly of subcellular components $\quad 35$

$\begin{array}{ll}\text { Regulation of assembly processes } & 37\end{array}$

$\begin{array}{ll}\text { Turnover and senescence } & 44\end{array}$

Meiosis and fertilisation $\quad 46$

2. The Cell Wall 49

The Components of the Cell Wall $\quad 49$

Polysaccharides $\quad 49$

Lignin $\quad 59$

$\begin{array}{ll}\text { Cell wall protein } & 60\end{array}$

Other cell wall components $\quad 61$

The Assembly of the Primary Cell Wall 62

$\begin{array}{ll}\text { Cell plate formation } & 62\end{array}$

Subsequent development of the primary cell wall 63

The Composite Structure and Properties of the Primary Cell Wall 67

$\begin{array}{ll}\text { Structure } & 67\end{array}$

Mechanical properties and the mechanism of extension 70 
The Secondary Cell Wall $\quad 79$

$\begin{array}{lr}\text { Assembly } & 79\end{array}$

$\begin{array}{ll}\text { Differentiation } & 80\end{array}$

The secondary cell wall: structure and function $\quad 88$

3. Structures Associated with Catabolism 91

The Mitochondrion $\quad 93$

Morphological, chemical and physical properties of the mitochondrial membranes

The intramitochondrial localisation of enzymes 102

Organisation and operation of the respiratory chain 104

$\begin{array}{ll}\text { Oxidative phosphorylation } & 106\end{array}$

The permeability of the inner membrane to anions 113

Conformational changes in mitochondrial structure $\quad 116$

$\begin{array}{ll}\text { Lysosomes } & 118\end{array}$

$\begin{array}{ll}\text { Peroxisomes and Glyoxysomes } & 121\end{array}$

4. The Photosynthetic Apparatus of Higher Plants 125

The Structure of the Mature Higher Plant Chloroplast 125

$\begin{array}{ll}\text { The chloroplast envelope } & 128\end{array}$

$\begin{array}{ll}\text { The chloroplast stroma } & 128\end{array}$

$\begin{array}{ll}\text { The granal fretwork system } & 134\end{array}$

$\begin{array}{ll}\text { Chloroplast Development } & 138\end{array}$

The development of proplastids into chloroplasts 138

The development of etioplasts into chloroplasts 141

$\begin{array}{ll}\text { Chloroplast Function } & 142\end{array}$

The process of photosynthesis 143

5. Water Relations 157

$\begin{array}{ll}\text { Some Basic Physics } & 157\end{array}$

$\begin{array}{ll}\text { Surface and capillary forces } & 157\end{array}$

$\begin{array}{ll}\text { Flow } & 159\end{array}$

$\begin{array}{ll}\text { Cell Water Relations } & 160\end{array}$

$\begin{array}{ll}\text { Forces acting } & 161\end{array}$

Examples: cell water content and potential 163

Determination of tissue water potential 166

$\begin{array}{ll}\text { Permeability of cells } & 166\end{array}$

$\begin{array}{ll}\text { Water Movement through the Plant } & 167\end{array}$

$\begin{array}{ll}\text { Water in the soil } & 170\end{array}$

Water uptake by the root $\quad 172$

$\begin{array}{ll}\text { Xylem } & 179\end{array}$

Water movement in the leaf $\quad 183$

The soil-plant-atmosphere continuum $\quad 183$

$\begin{array}{lr}\text { Adaptation } & 185\end{array}$

Control of water loss $\quad 185$

Efficiency of water uptake $\quad 186$

Cellular adaptation 191 - 
6. Mineral Nutrition 197

Nutrient Uptake 202

The adaptability of roots in relation to nutrient uptake 202

The soil micro-flora and its effects on nutrient uptake 206

Selective salt uptake $\quad 211$

Mineral Supply and Plant Growth 219

Elements having positive effects on plant growth 221

Nitrogen fixation in wild and domesticated plants 225

Phosphorus nutrition of plants growing in cultivated and noncultivated soils 229

Potassium 235

Elements having adverse effects on plant growth 237

7. Transport in the Phloem 254

The Distribution of Substances by the Phloem 254

The phloem as the assimilate carrier 254

The analysis of phloem sap $\quad 255$

The significance of sources and sinks 257

Entry into the phloem and assimilate export 257

Patterns of assimilate distribution $\quad 261$

The demand for assimilates 265

Effects of parasites on assimilate distribution $\quad 268$

Phloem transport and plant nutrition $\quad 273$

The transport of foreign substances 275

Quantitative aspects of assimilate transport 278

Mechanisms of Phloem Transport 279

Structure of the phloem $\quad 279$

Sieve tubes $\quad 280$

Physiological contributions $\quad 282$

Hypotheses of the mechanism 283

Integration of structure and function 290

8. Photosynthesis: Leaf and Whole Plant Aspects 294

Structure of Foliage Leaves 294

Diffusion Pathways for Carbon Dioxide and Water 297

The gaseous diffusion pathway 297

The liquid diffusion pathway 299

The role of stomata in the gaseous diffusion pathway $\quad 300$

Movements of stomata 303

Factors Determining Resistance to Carbon Dioxide Transport in the Liquid Phase: $R_{\text {liq }}^{\prime}$ in C4 Plants 305

Compartmentation within the mesophyll cell: carbon dioxide compensation and photorespiration in C3 and C4 plants $\quad 307$

Leaf Anatomy in Relation to the C4 Pathway of Photosynthesis 309

The Response of Photosynthesis to Environmental Factors $\quad 310$

$\begin{array}{ll}\text { Light } & 311\end{array}$ 
$\begin{array}{ll}\text { Carbon dioxide } & 312\end{array}$

Temperature $\quad 313$

$\begin{array}{ll}\text { Oxygen } & 314\end{array}$

Structural Changes Associated with Environmental Factors $\quad 314$

$\begin{array}{ll}\text { Adaptations of xerophytes } & 316\end{array}$

Adaptation to different light levels $\quad 319$

Photosynthesis in the Whole Plant and in Plant Communities 321

$\begin{array}{ll}\text { The whole plant } & 321\end{array}$

Plant communities $\quad 322$

9. The Angiosperm Flower and Related Structures 326

$\begin{array}{ll}\text { The Early Angiosperms } & 327\end{array}$

Cretaceous fossils $\quad 327$

Reasons for the lack of fossils $\quad 329$

The chromosome number of the earliest angiosperms 331

The origin of the angiosperm flower $\quad 332$

Monophyletic or polyphyletic? $\quad 334$

Modifications to the Angiosperm Flower and Associated Structures during the Course of Evolution $\quad 335$

Sepals $\quad 335$

Petals $\quad 335$

Stamens $\quad 337$

Pollen $\quad 339$

Carpels $\quad 342$

Ovules $\quad 344$

Fruits $\quad 348$

$\begin{array}{ll}\text { Seeds } & 349\end{array}$

Modifications to the whole flower $\quad 350$

Floral Pigments $\quad 353$

Flavonoid pigments $\quad 353$

Some other floral pigments $\quad 357$

Pigments in pollen $\quad 358$

Significance of pigments in pollination $\quad 359$

Significance of pigments in fruit dispersal $\quad 360$

Genetics of floral pigments $\quad 360$

Distribution of floral pigments $\quad 361$

$\begin{array}{ll}\text { Floral scents } & 362\end{array}$

Flower Structure in Relation to Breeding Systems 363

Why Floral Patterns are so Conservative $\quad 364$

Insect Pollinators $\quad 365$

Some primitive insects $\quad 365$

The more advanced insects $\quad 366$

$\begin{array}{ll}\text { Pollination by Birds } & 367\end{array}$

$\begin{array}{ll}\text { Other Pollinators } & 367\end{array}$

A Few Examples of Pollination $\quad 368$

Ranunculus ficaria $\quad 369$

Erica tetralix $\quad 369$ 
Vaccinium myrtillus $\quad 369$

Lamium album $\quad 370$

Linaria vulgaris $\quad 371$

Digitalis purpurea $\quad 372$

Arum maculatum $\quad 372$

Dactylorhiza maculata $\quad 374$

The flowers of grasses $\quad 374$

10. The Plant Life-cycle and the Environment 379

Adaptation to Seasonal Changes $\quad 380$

$\begin{array}{ll}\text { The Active Phase of the Annual Life-cycle } & 381\end{array}$

Environmental Control of the Life-cycle $\quad 385$

Photoperiodism $\quad 385$

$\begin{array}{ll}\text { Vernalisation } & 391\end{array}$

Internal factors affecting flowering $\quad 395$

The Dormancy Phase $\quad 396$

Seasonal Changes and the Annual Life-cycle 400

Ecotypic Variation with Latitude and Altitude 402

Cold Resistance $\quad 404$

Freezing tolerance $\quad 410$

Plant Responses to Short-term Environmental Changes 412

Phytochrome and photomorphogenesis $\quad 413$

Ecological aspects of photomorphogenesis $\quad 418$

Index $\quad 424$ 


\section{Preface}

In the last ten to twenty years the trend in all branches of plant science has been away from the descriptive to the experimental. During the same period such has been the explosion in knowledge that teachers at all levels have been faced with either selecting particular parts of their subject and treating them in some detail or trying to cover the whole field, which necessarily results in trivialisation of many aspects. The study of plant structure has been one casualty of this syndrome and while in the past a disproportionate amount of time was devoted to this aspect, the pendulum has swung so far in the opposite direction that the result is a generation of students whose understanding of plant processes is handicapped by an insufficient appreciation of the framework in which they occur. A return to past methods would be impractical but it seems to us that a middle course is possible which this book seeks to follow at a level suitable for first- or second-year undergraduates.

The first four chapters deal with the interdependence of structure and function at the molecular and subcellular level, but in addition some stress is placed on the manner in which individual structures-from the complex molecule upwards - are assembled and how such assembly may be controlled. In the four succeeding chapters major plant functions are dealt with in relation to the structures associated with them. At the same time, adaptation in both form and function is discussed. Chapter 9 concerns the angiosperm flower and associated structures. We include this section, not only for the obvious reason that we could not omit a discussion of the reproductive apparatus and how this is adapted to its particular role, but also because it provides an opportunity for following the evolution of a specific plant organ and showing how this has been adapted to suit different conditions through the ages. This is distinct from adaptation as dealt with in the rest of the book. where we are concerned with adaptations to present-day conditions. In the last chapter the relationship between the plant life-cycle and the environment is reviewed, particular attention being paid to the ways in which plants are equipped to cope with environmental changes (in terms of structure or physiological response) and how such changes are perceived. While this involves the introduction of new material it is also an attempt to put much of what has gone before into perspective.

This book does not, however, attempt to deal comprehensively with both structure and function, details of these must be sought in textbooks devoted entirely to one or the other. Inevitably omissions have been made, since to include all aspects would result in a work too expensive to buy for those at whom it is aimed. What we hope we have achieved is an account which brings together aspects of the subject which are usually treated separately, in order that the reader can visualise the plant as an integrated entity. 
Each chapter has been written by an expert in the field. We have chosen this method because it has become increasingly difficult for any one botanist to be able to write authoritatively on the range of subjects treated here. Consequently, the authors range from biochemists through physiologists to genecologists and ecologists. This fact, perhaps more than anything else, indicates that such a book is needed.

We have not included extensive reference lists since we feel that at this level the average student will neither have the time to read many original publications nor indeed be able to decide which are likely to be most important. However, at the end of each chapter there are short lists of further reading which include reviews, symposia and a few significant original publications.

A certain basic knowledge has had to be assumed, principally of chemistry and biochemistry, but since these form part of most first-year courses in botany we were reluctant to include too much material which would in any case be dealt with more thoroughly in conventional textbooks on these subjects.

I am grateful to the many people who have contributed in different ways in the preparation of this book, but in particular I would like to thank Professor P. F. Wareing, F.R.S., and Charles Fry of Macmillan Press for their advice and helpful criticism, my wife for much help in preparing the manuscript and Mrs D. Redmond and Mrs J. Crawford for typing. 


\section{List of Contributors}

R. M. M. Crawford, Department of Botany, University of St Andrews

M. A. Hall (editor), Department of Botany and Microbiology, University College of Wales, Aberystwyth

Michael B. Jones, Department of Biological Sciences, University of Lancaster Rachel M. Leech, Department of Biology, University of York

T. A. Mansfield, Department of Biological Sciences, University of Lancaster

C. Marshall, School of Plant Biology, University College of North Wales, Bangor

E. I. Newman, Department of Botany, University of Bristol

J. M. Palmer, Department of Botany, Imperial College of Science and Technology

G. R. Sagar, School of Plant Biology, University College of North Wales, Bangor

J. P. Savidge, Department of Botany and Microbiology, University College of Wales, Aberystwyth

Howard Thomas, Welsh Plant Breeding Station, Plas Gogerddan, Aberystwyth

P. F. Wareing, Department of Botany and Microbiology, University College of Wales, Aberystwyth 